\title{
Monitoring House Fly, Musca domestica (Diptera: Muscidae), Populations in Caged-Layer Poultry Houses Using a Baited Jug-Trap ${ }^{1}$
}

\author{
J. G. BURG ${ }^{2}$ AND R. C. AXTELL ${ }^{3}$ \\ Department of Entomology, North Carolina State University, \\ Raleigh, North Carolina 27695-7613
}

\begin{abstract}
Environ. Entomol. 13: 1083-1090 (1984)
ABSTRACT A baited jug-trap for sampling house fly populations is described. We found trapping of house flies to be most effective at the roof peak in a narrow caged-layer poultry house and ca. $1 \mathrm{~m}$ above the manure in a high-rise poultry house, using the jug-trap baited with Super Golden Malrin ${ }^{*}$, containing $0.025 \%$ 2-(1-methylethoxy) phenol methylcarbamate, $0.04 \%$ 2,2-dichlorovinyl dimethyl phosphate, and $0.025 \%(\mathrm{Z})$-9-tricosene. Yellow painted jug-traps caught more house flies than red, green, blue, black, or white. The period of greatest fly catches in the trap was between 1200 and 1700 EST. Traps baited with the slowrelease synthetic house fly attractant ( $88 \%$ fishmeal, $5 \%$ trimethylamine hydrochloride, $5 \%$ ammonium sulfate, $1 \%$ indole, and $1 \%$ linoleic acid) caught fewer flies than traps baited with Improved Golden Malrin ${ }^{\star}$, containing $1.0 \%$ methomyl (S-methyl $N$-[methylcarbamoyl] oxy) thioacetimidate and $0.025 \%$ (Z)-9-tricosene, or Super Golden Malrin, and caught more flies than traps baited with Golden Malrin ${ }^{8}$, containing $0.093 \%$ 2,2-dichlorovinyl dimethyl phosphate and $0.25 \%$ 0,0-dimethyl 0-(2,4,5-trichlorophenyl) phosphorothioate, when tested in a narrow caged-layer poultry house. Indole was found to be the most attractive chemical in the synthetic formulation and ammonium sulfate decreased the attractiveness of the formulation. We advocate the use of a white, translucent jug-trap baited with $25 \mathrm{~g}$ of Improved Golden Malrin and hung at the level of the upper cages as a simple, practical method for monitoring house fly populations in caged-layer houses.
\end{abstract}

ADUlt HOUSE fly (Musca domestica L.) monitoring techniques are an important part of a integrated fly management program (Axtell 1970a,b, 1981a,b). Many different techniques and baits for sampling flies have been reported, with considerable variability in the published results. Sampling methods include direct observations (grills and attractants), baited traps, sticky traps, light traps, vacuum sweeps, and counted fly specks on paper, plastic, or glass sheets. Ground level placement of traps has been used for control of flies and studies on spatial and temporal movement of flies in poultry houses (Keller et al. 1956, Willson and Mulla 1975). Pickens et al. (1975) studied the effect of position on fly catches in light traps with and without bait in dairy barns and controlled temperature chambers. The effect of position of baited traps in poultry houses was studied by Mitchell et al. (1975). Color preference tests have been performed by a number of experimenters. Freeborn and Berry (1935) counted fly specks on a plywood board painted with various colors and placed in a dairy barn. Waterhouse (1947) observed the numbers and duration of flies resting on colored plywood sur-

${ }^{1}$ This article reports the results of research only, Mention of a proprietary product does not constitute an endorsement or a recommendation for its use.

${ }^{2}$ Present address: Dept. of Entomology, Pennsylvania State Univ., University Park, PA 16802.

${ }^{3}$ To whom reprint requests should be addressed. faces in a Peet-Grady chamber. Hecht (1963) observed flies resting on various shades of white and black paper. Hecht (1970) reviewed the literature on the response of house flies to light and color, and concluded that the color was not as important an attractant as the contrast between the color and its surroundings and the amount of luster of the surface. Mitchell et al. (1975) combined baited piepan traps and colors to determine the attractiveness of the colors to house flies. Axtell (1970a) used sticky ribbons and white cards to evaluate fly populations, and advocated using counts of fly specks on the cards as a measure of fly activity.

A variety of substances have been tested as attractants to lure flies to baited traps. Among the complex mixtures attractive to house flies are brewers' malt and blackstrap molasses (Gahan et al. 1953), sucrose, urea, blood mixture (Pickens et al. 1973), and freeze-dried fermented whole egg solids (Willson and Mulla 1973). Brown et al. (1961) studied the attractiveness of sugars, amines, halogenated compounds, ethers, aldehydes and ketones, and alcohols to house flies, and compared mixtures and single chemicals. The house fly sex pheromone, (Z)-9-tricosene, acts as an aggregation attractant to both male and female house flies (Carlson and Beroza 1973), and is used in some commercial sugar-toxicant baits. Mulla et al. (1977) stated that a bait formulation consisting of indole, trimethylamine hydrochloride, linoleic acid, and 


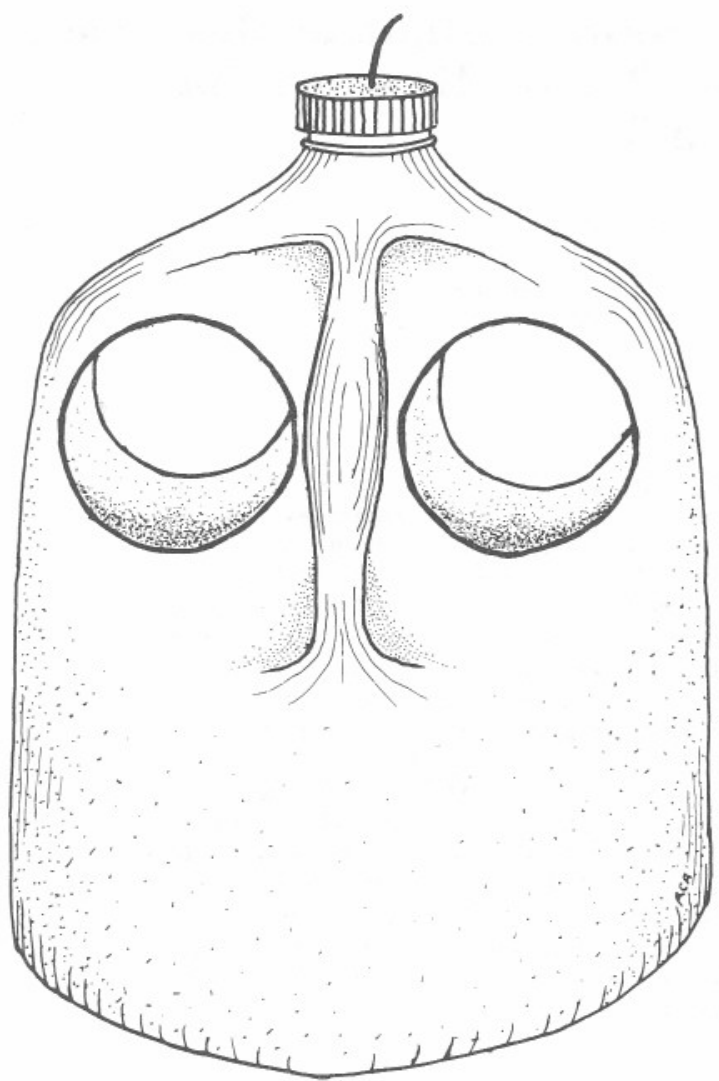

Fig. 1. Baited jug-trap (see text).

ammonium sulfate was superior to many other baits which were tested in house fly traps in California poultry houses.

In an effort to develop a standardized fly monitoring method for poultry houses, we designed a simple trap and evaluated the effects of trap position, color, time of day, and bait composition. All evaluations were conducted under natural field conditions, i.e., in poultry houses with naturallyoccurring populations of house flies.

\section{Methods and Materials}

Trap Design. The standard trap (Fig. 1) was a 3.87-liter translucent white plastic jug (a common "1-gal" milk jug, $4 \mathrm{~cm}$ diam by $25 \mathrm{~cm}$ high) with four 5-cm-diameter access holes equidistant around the circumference in the upper third of the jug, about $8 \mathrm{~cm}$ below the screwtop (4 cm diam). A wire was attached to the screwtop for hanging. The access holes were made using a heated metal tube. The standard bait (SGM) scattered on the inside bottom of the jug was $25 \mathrm{~g}$ of Super Golden Malrin ${ }^{\circledR}$ (Zoecon Industries, Dallas, Tex.), composed of $0.025 \% 2$-(1-methylethoxy) phenol methylcarbamate (propoxur), 0.04\% 2,2-dichlorovinyl dimethyl phosphate (dichlorvos), and $0.025 \%(Z)$ -

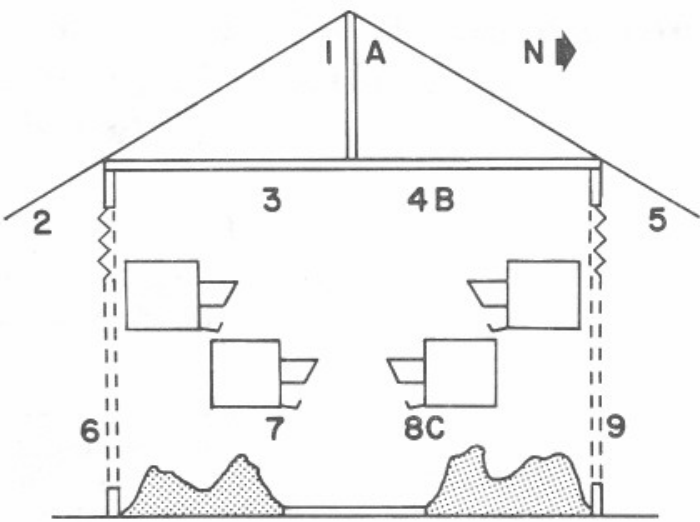

Fig. 2. Diagram of a cross section of the open-sided narrow caged-layer poultry house showing the position of traps $(1-9)$ in the location effects experiments and in the time of day experiments (A-C).

9-tricosene (muscalure). Preliminary tests using various quantities of bait demonstrated that $25 \mathrm{~g}$ was optimal, because with less than $25 \mathrm{~g}$ fewer flies were caught and with more than $25 \mathrm{~g}$ there were only slight increases in the number trapped.

Trap Location. The numbers of flies collected in the standard baited jug-trap were determined at various locations within two types of caged-layer poultry houses: narrow and high-rise. Both houses had adjustable plastic curtains along the open sides for regulating the temperature within. The narrow ("California-type") house (Wake County, N.C.) was 3 by $40 \mathrm{~m}$, with a row of twotiered cages on each side of a center concrete walkway (Fig. 2). The manure accumulated on the ground, ca. $1 \mathrm{~m}$ below the cages. The house was divided into equal sections ( $5 \mathrm{~m}$ long) each containing 40 cages ( 10 cages per tier, $2-3$ birds per cage). The two-story high-rise ("deep pit type") house (Chatham County, N.C.) was 13 by $163 \mathrm{~m}$, with the birds housed in the upper story in eight rows of two-tiered cages ( 3 birds per cage) divided by five walkways (Fig. 3). The manure accumulated on the ground, ca. $4 \mathrm{~m}$ below the cages, in the lower story.

In the narrow house the baited jug-traps were placed in nine locations (Fig. 2): (1) $2.8 \mathrm{~m}$ above the walkway, near the roof peak; (2 and 5) $1.7 \mathrm{~m}$ above the walkway at the eaves (outside south and north sides of the house); ( 3 and 4) $1.8 \mathrm{~m}$ above the walkway, hung from the rafters (south and north sides of the walkway); (6 and 9) $0.6 \mathrm{~m}$ above the walkway, outside on the south and north sides of the house; and (7 and 8) hung from the lower cage row at manure level $0.6 \mathrm{~m}$ above the walkway on the south and north sides. All nine locations were used in each of four alternate sections of the house on each test day (four replications per location per day). There were three test days between 9 and 21 June 1978. Four thermographs were placed at various positions in the house to 


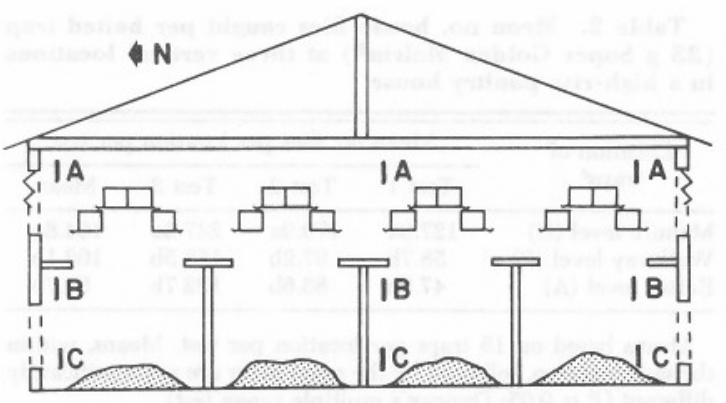

Fig. 3. Diagram of a cross section of the open-sided high-rise poultry house showing the vertical (A-C) and west end horizontal (1) placement of traps in the location effects experiment. See text for explanation of other horizontal locations (2-5).

determine the temperature range during each test. The mean numbers of flies caught per treatment in each test were compared by analysis of variance (ANOVA) and Duncan's multiple range test.

In the high-rise house, baited jug-traps were placed at three heights (vertical locations) at each of five locations along the length of the house (horizontal locations) (Fig. 3). The vertical locations were (A) $2.4 \mathrm{~m}$ above the walkway, hung from the rafters; (B) $0.1 \mathrm{~m}$ below the walkway; and (C) 0.9 $\mathrm{m}$ above the manure. The horizontal locations were (1) the west end of the house; (2) the north outside walkway; (3) the center walkway; (4) the south outside walkway; and (5) the east end of the house. There was a total of 45 traps in the house, arranged in a three-dimensional grid with 15 traps at each vertical location and 3 at each horizontal location at each height. Baited traps were placed at all positions for $24 \mathrm{~h}$ on each of three test days (12-15 June 1979). Four thermographs were at various positions in the house to determine the temperature range during each test. The mean numbers of flies caught per position in each test were compared by analysis of variance and Duncan's multiple range test.

Trap Color. The standard translucent white jugtrap baited with SGM was painted to compare the effects of six colors on the number of house flies caught. The paints were: red (\#105 chinese red), green (\#108 forest green), blue (\#106 majestic blue), black (\#104 universal black), and yellow (\#109 bright yellow) (Dap Inc., Dayton, Ohio). Unpainted traps were used for the white color. Six sections of the narrow poultry house were used in the 6 by 6 Latin square experimental design, each treatment color appearing once in each section. The traps were all placed $1.8 \mathrm{~m}$ above the walkway (hung from the rafters) in six equally spaced (ca. $1.2 \mathrm{~m}$ ) positions. No single colored trap appeared more than once at each position within the six sections. The temperature range during each test was determined using four thermographs placed at various positions in the house. Three 24-h tests were conducted between 5 and 15 July
1978. The mean numbers of flies caught per treatment (color) in each test were compared by analysis of variance and Duncan's multiple range test.

Time of Day. The standard baited jug-traps were placed in three locations in the narrow house to study the effects of time of day on trap catches of house flies, during a 21-h period. The locations were (Fig. 2) (A) $2.8 \mathrm{~m}$ above the walkway, near the roof peak; (B) $1.8 \mathrm{~m}$ above the walkway, hung from the rafters; and (C) $0.6 \mathrm{~m}$ above the walkway, hung from the cage rows (manure level). Four alternate sections within the house were used in the test, with each test replicated in each section (eight replications per location). Within each section a trap was at least $1.2 \mathrm{~m}$ from the next nearest trap. The traps were positioned at 0400 EST and counts were made every $3 \mathrm{~h}$ until 0100 the following day. After each count the traps were replaced, with none of the flies caught being removed. The incandescent lights were on from 0500 to 0800 and 1900 to 2200 EST.

Bait Formulations. Four bait formulations were tested for their effectiveness in attracting the house fly. Three of the formulations were commercially produced (Zoecon Industries, Inc., Dallas, Tex.): Golden Malrin ${ }^{\circledR}$ sugar bait (GM) containing $0.093 \%$ 2,2-dichlorovinyl dimethyl phosphate (dichlorvos) and $0.25 \% \quad 0,0$-dimethyl 0 -(2,4,5-trichlorophenyl) phosphorothioate (ronnel); Super Golden Malrin ${ }^{\circledR}$ fly bait (SGM) containing $0.025 \%$ 2-(1-methylethoxy) phenol methylcarbamate (propoxur), $0.04 \%$ 2,2-dichlorovinyl dimethyl phosphate (dichlorvos), and $0.025 \%(Z)-9$-tricosene (muscalure); and Improved Golden Malrin ${ }^{\circledR}$ fly bait (IGM) containing $1.0 \%$ (S-methyl $N$-[methylcarbamoyl] oxy) thioacetimidate (methomyl) and $0.025 \%(\mathrm{Z})$-9-tricosene (muscalure). The fourth was a slow-release synthetic fly attractant formulation (SFA) described by Mulla et al. (1977), and composed of $88 \%$ commercial fishmeal; $5 \%$ ammonium sulfate $\left(\mathrm{NH}_{4}\right)_{2} \mathrm{SO}_{4},(\mathrm{AS}) ; 5 \%$ trimethylamine hydrochloride $\left(\mathrm{CH}_{3}\right)_{3} \mathrm{~N} \cdot \mathrm{HCl}$, (TRH); $1 \%$ linoleic acid $\left(\mathrm{C}_{18} \mathrm{H}_{32} \mathrm{O}_{2}\right)$, (LA); and $1 \%$ indole $\mathrm{C}_{6} \mathrm{H}_{4} \mathrm{NHCH}: \mathrm{CH}$, (I). All of the chemicals used had a purity of over $95 \%$. The SFA formulation was mixed in a $1: 1$ ratio (wt:wt) with Golden Malrin ${ }^{\circledR}$ to yield a total of $25 \mathrm{~g}$ of bait. The SFA formulation was used as the attractive part of the bait, while the GM contained the insecticide needed to kill the attracted flies. The baits were tested in the standard trap, with $25 \mathrm{~g}$ of the bait scattered on the inside bottom of the jug.

The baits were compared in the open-sided narrow caged-layer poultry house (Fig. 2) using a Latin square experimental design. Each treatment trap appeared once in each of four or five sections depending upon the number of treatments. In each section the traps were suspended from the rafters, $1.8 \mathrm{~m}$ above the walkway, with no single treatment trap appearing more than once at each position within the four or five sections in an experiment. The traps were equidistant (ca. $1.2 \mathrm{~m}$ ) from 
Table 1. Mean no. house flies caught per day per baited trap ( $25 \mathrm{~g}$ Super Golden Malrin ${ }^{(3)}$ at nine locations in a narrow caged-layer poultry house

\begin{tabular}{llrlc}
\hline \hline \multirow{2}{*}{$\begin{array}{c}\text { Location of } \\
\text { traps }\end{array}$} & \multicolumn{4}{c}{ Mean no. flies per location per test } \\
\cline { 2 - 5 } & \multicolumn{1}{c}{ Test 1 } & Test 2 & Test 3 & Mean \\
\hline Roof peak (1) & $47.5 \mathrm{ab}$ & $40.0 \mathrm{a}$ & $91.0 \mathrm{a}$ & $59.50 \mathrm{a}$ \\
Rafter, south side (3) & $59.2 \mathrm{a}$ & $33.2 \mathrm{a}$ & $52.8 \mathrm{~b}$ & $48.42 \mathrm{ab}$ \\
Rafter, north side (4) & $45.5 \mathrm{ab}$ & $16.8 \mathrm{~b}$ & $45.0 \mathrm{bc}$ & $35.75 \mathrm{~b}$ \\
Manure, north side (8) & $33.8 \mathrm{bc}$ & $9.8 \mathrm{~b}$ & $12.5 \mathrm{c}$ & $18.67 \mathrm{c}$ \\
Manure, south side (7) & $17.0 \mathrm{c}$ & $7.0 \mathrm{~b}$ & $13.0 \mathrm{c}$ & $12.33 \mathrm{c}$ \\
Eaves, north side (5) & $11.5 \mathrm{c}$ & $9.0 \mathrm{~b}$ & $13.8 \mathrm{c}$ & $11.42 \mathrm{c}$ \\
Eaves, south side (2) & $11.5 \mathrm{c}$ & $8.2 \mathrm{~b}$ & $12.5 \mathrm{c}$ & $10.75 \mathrm{c}$ \\
Outside, south side (6) & $12.8 \mathrm{c}$ & $9.2 \mathrm{~b}$ & $8.2 \mathrm{c}$ & $10.08 \mathrm{c}$ \\
Outside, north side (9) & $12.8 \mathrm{c}$ & $6.2 \mathrm{~b}$ & $6.5 \mathrm{c}$ & $8.50 \mathrm{c}$ \\
\hline
\end{tabular}

Means based on four traps per location per test. Means, within the same column, followed by the same letter are not significantly different $(P=0.05$; Duncan's multiple range test).

${ }^{a}$ See Fig. 2.

each other. Five experiments were conducted (19 July-27 Sept. 1978), using a 4 by 4 Latin square design in the first four and a 5 by 5 design in the fifth experiment. Each of the experiments consisted of four tests, each test having a duration of $24 \mathrm{~h}$.

Experiment 1 compared the attractiveness of all four formulations. Experiment 2 included the four formulations with the SFA formulation enhanced by the addition of $400 \mathrm{~g}$ of sand and $100 \mathrm{ml}$ of water to aid in the release of gaseous trimethylamine and ammonia from trimethylamine hydrochloride and ammonium sulfate, respectively. Experiments 3,4 , and 5 were designed to determine which components of the SFA formulation were most attractive to the house fly. When the entire SFA formulation was not used, the chemicals were presented in the bait at the concentration (by weight) found in the intact SFA formulation. GM $(12.5 \mathrm{~g})$ was used with each chemical component bait to supply the insecticide and a trap with 25 g. SGM was used as a standard. Experiment 3 compared the attractiveness of SGM, SFA, fishmeal, and the four chemicals (TRH, I, LA, and AS). Experiment 4 compared SGM, TRH $+\mathrm{I}+\mathrm{LA}, \mathrm{TRH}+\mathrm{I}$, and $\mathrm{TRH}+\mathrm{I}+\mathrm{AS}$ in attracting flies. Experiment 5 compared the attractiveness of SGM and each of the four chemical constituents of SFA separately. The mean numbers of flies caught per treatment in each test were compared by analysis of variance and Duncan's multiple range test.

\section{Results}

Location Effect. In the narrow house, the traps located near the roof peak and rafter level caught the most flies on all 3 days (Table 1). There were no significant ( $P=0.05$; ANOVA) differences in the numbers of flies caught in the remaining six locations. The temperature during all three tests was between 18 and $33^{\circ} \mathrm{C}$ for the entire 24 -h test period, resulting in high house fly activity.

In the high-rise house, the traps located at the
Table 2. Mean no. house flies caught per baited trap (25 g Super Golden Malrin ${ }^{(2)}$ ) at three vertical locations in a high-rise poultry house

\begin{tabular}{lrrrr}
\hline \hline \multirow{2}{*}{$\begin{array}{c}\text { Location of } \\
\text { traps }\end{array}$} & \multicolumn{4}{c}{ Mean no. flies per location per test } \\
\cline { 2 - 5 } & Test 1 & Test 2 & Test 3 & Mean \\
\hline Manure level (C) & $127.3 \mathrm{a}$ & $179.9 \mathrm{a}$ & $247.3 \mathrm{a}$ & $184.8 \mathrm{a}$ \\
Walkway level (B) & $58.7 \mathrm{~b}$ & $97.2 \mathrm{~b}$ & $153.5 \mathrm{~b}$ & $103.1 \mathrm{~b}$ \\
Rafter level (A) & $47.8 \mathrm{~b}$ & $83.6 \mathrm{~b}$ & $122.7 \mathrm{~b}$ & $84.7 \mathrm{~b}$ \\
\hline
\end{tabular}

Means based on 15 traps per location per test. Means, within the same column, followed by the same letter are not significantly different ( $P=0.05$; Duncan's multiple range test).

${ }^{a}$ See Fig. 3

level of the manure caught more house flies than the walkway and rafter level traps on all 3 test days $(P=0.05$; ANOVA) (Table 2$)$. The comparisons of fly catches at the different horizontal locations revealed no significant differences except for the center traps, which caught the fewest flies at the rafter level in all three tests, and the north side traps, which caught fewer flies than the west end traps at the walkway level (Table 3 ). The temperature was above $18^{\circ} \mathrm{C}\left(16-31^{\circ} \mathrm{C}\right)$ for $18 \mathrm{~h}$ on test days 1 and 3 , and above $18^{\circ} \mathrm{C}\left(19-31^{\circ} \mathrm{C}\right)$ for $24 \mathrm{~h}$ on day 2 at the rafter level; at the walkway level the temperature was above $18^{\circ} \mathrm{C}\left(13-28^{\circ} \mathrm{C}\right)$ for $17 \mathrm{~h}$ on all 3 test days; and at the manure level the temperature was above $18^{\circ} \mathrm{C}\left(16-27^{\circ} \mathrm{C}\right)$ for 13 $\mathrm{h}$ on all 3 test days.

Color Preference. Overall, the yellow traps caught more house flies and the white traps caught fewer flies than the other colors in the three tests (Table 4). Results varied among the three experiments, with $(P=0.05$; ANOVA $)$ differences among the traps when the highest fly population was present (Expt. 3). The red, green, black, and blue traps caught flies with different degrees of effectiveness in the three tests. The temperature was above $18^{\circ} \mathrm{C}$ for between 15 and $17 \mathrm{~h}\left(14-29^{\circ} \mathrm{C}\right)$ during test days 1 and 2 , and was above $18^{\circ} \mathrm{C}$ for $24 \mathrm{~h}(21-$ $31^{\circ} \mathrm{C}$ ) during test day 3 .

Time of Day. There was a change in the number of flies trapped at each of the three positions in the narrow house during the light hours of the day (Fig. 4). The roof-peak and rafter-level traps caught approximately equal numbers of flies during the 21 -h test period. The roof peak traps caught the most flies at $0700,1600,1900$, and $2200 \mathrm{~h}$; the rafter level traps caught the most flies at 1000 and $1300 \mathrm{~h}$; and both positioned traps caught equal numbers of flies at $0100 \mathrm{~h}$. The manure-level traps caught the least number of flies during the 2l-h test period. At the roof peak and rafter level the traps caught large numbers of flies between 1300 and $1900 \mathrm{~h}$, with a peak catch at $1600 \mathrm{~h}$. There was only a slight change in numbers caught at the manure-level position during the test period. In general, house fly activity, measured by the numbers of flies trapped during 3 -h intervals, increased at the start of artificial light, reached a peak between 1600 and $1900 \mathrm{~h}$, and then declined by 0100 
Table 3. Mean no. house flies eaught per baited trap (25 g Super Golden Malrin ${ }^{8}$ ) at five horizontal locations at three vertical levels in a high-rise poultry house

\begin{tabular}{|c|c|c|c|c|}
\hline \multirow{2}{*}{$\begin{array}{l}\text { Location of } \\
\text { traps }\end{array}$} & \multicolumn{4}{|c|}{ Mean no. flies per location per test } \\
\hline & Test 1 & Test 2 & Test 3 & Mean \\
\hline & \multicolumn{4}{|c|}{ Rafter level (A) } \\
\hline West end & $70.3 \mathrm{a}$ & $100.0 \mathrm{a}$ & $118.0 \mathrm{a}$ & $96.1 \mathrm{a}$ \\
\hline North side & $48.3 \mathrm{a}$ & $103.7 \mathrm{a}$ & $120.0 \mathrm{a}$ & $90.8 \mathrm{a}$ \\
\hline Center & $8.7 \mathrm{~b}$ & $31.0 \mathrm{a}$ & $31.7 \mathrm{~b}$ & $23.8 b$ \\
\hline South side & $70.0 \mathrm{a}$ & $92.3 a$ & $185.0 \mathrm{a}$ & $117.1 \mathrm{a}$ \\
\hline \multirow[t]{2}{*}{ East end } & $37.3 \mathrm{ab}$ & $91.0 \mathrm{a}$ & $158.7 \mathrm{a}$ & $95.7 \mathrm{a}$ \\
\hline & \multicolumn{4}{|c|}{ Walkway level (B) } \\
\hline West end & $114.0 \mathrm{a}$ & $150.3 \mathrm{a}$ & $205.0 \mathrm{a}$ & $156.4 \mathrm{a}$ \\
\hline North side & $26.3 \mathrm{~b}$ & $72.0 \mathrm{a}$ & $126.0 \mathrm{a}$ & $74.8 \mathrm{~b}$ \\
\hline Center & $46.7 \mathrm{~b}$ & $95.0 \mathrm{a}$ & $155.0 \mathrm{a}$ & $98.9 \mathrm{ab}$ \\
\hline South side & $58.3 \mathrm{~b}$ & $82.3 a$ & $139.7 \mathrm{a}$ & 93.4ab \\
\hline \multirow[t]{2}{*}{ East end } & $48.0 \mathrm{~b}$ & $86.3 \mathrm{a}$ & $142.0 \mathrm{a}$ & $92.1 \mathrm{ab}$ \\
\hline & \multicolumn{4}{|c|}{ Manure level $(C)$} \\
\hline West end & $150.0 \mathrm{a}$ & $221.7 \mathrm{a}$ & $276.7 \mathrm{a}$ & $216.1 \mathrm{a}$ \\
\hline North side & $105.3 \mathrm{a}$ & $148.7 \mathrm{a}$ & $189.0 \mathrm{a}$ & $147.7 \mathrm{a}$ \\
\hline Center & $104.7 \mathrm{a}$ & $185.0 \mathrm{a}$ & $265.7 \mathrm{a}$ & $185.1 \mathrm{a}$ \\
\hline South side & $156.0 \mathrm{a}$ & $179.0 \mathrm{a}$ & $236.7 \mathrm{a}$ & $190.6 a$ \\
\hline East end & $120.3 \mathrm{a}$ & $165.0 \mathrm{a}$ & $268.7 \mathrm{a}$ & $184.7 \mathrm{a}$ \\
\hline
\end{tabular}

Means based on three traps per location within each level for each test. Means followed by the same letter within the same column within each level are not significantly different $(P=0.05$; Duncan's multiple range test).

h. The temperature was above $18^{\circ} \mathrm{C}\left(21-35^{\circ} \mathrm{C}\right)$ during the 21-h test period.

Bait Formulations. The results of the five experiments comparing bait formulations $(P=0.05$; ANOVA) are presented in Table 5. IGM-baited traps caught more flies than any other baited trap in all of the tests in both experiment 1 and experiment 2. SGM-baited traps caught more flies than SFA-baited traps, and SFA-baited traps caught more flies than GM-baited traps in all four tests in experiment 1 . Traps baited with SGM caught more flies than traps baited with $\mathrm{SFA}+\mathrm{H}_{2} \mathrm{O}$ in the first two tests, and fewer flies than traps baited with $\mathrm{SFA}+\mathrm{H}_{2} \mathrm{O}$ in the second two tests of experiment 2. GM-baited traps caught the least numbers of flies in all of the tests in experiment 2. Traps baited with SGM caught significantly more house flies than any of the other baited traps used in experiments 3 through 5, except in two tests where there was no statistical difference among the treatments due to high variance values of the treatments. In experiment 3, SFA-baited traps caught more flies than the fishmeal-baited traps or the traps baited with the four chemicals in three of the four tests. In experiment 4 , traps baited with $\mathrm{TRH}+\mathrm{I}+\mathrm{LA}$ caught as many as or more flies than traps baited with either TRH+I or TRH+I+AS, and traps baited with TRH+I caught as many as or more flies than traps baited with TRH+I+AS. In experiment 5, traps baited with indole consistently caught more flies than TRH-, LA-, or AS-baited traps, which caught approximately equal numbers of flies throughout the four tests.

SGM was used throughout the five experiments
Table 4. Mean no. house flies caught per colored bait trap (25 $\mathrm{g}$ Super Golden Malrin $\left.{ }^{\star}\right)$ in a narrow caged-layer poultry house

\begin{tabular}{lcccc}
\hline \hline \multirow{2}{*}{$\begin{array}{l}\text { Color } \\
\text { of trap }\end{array}$} & \multicolumn{4}{c}{ Mean no. flies per color per test } \\
\cline { 2 - 5 } & Test 1 & Test 2 & Test 3 & Mean \\
\hline Yellow & $38.8 \mathrm{a}$ & $63.8 \mathrm{a}$ & $102.3 \mathrm{a}$ & $68.33 \mathrm{a}$ \\
Red & $21.5 \mathrm{ab}$ & $36.7 \mathrm{ab}$ & $78.8 \mathrm{a}$ & $45.67 \mathrm{~b}$ \\
Green & $14.8 \mathrm{~b}$ & $43.7 \mathrm{ab}$ & $78.0 \mathrm{a}$ & $45.50 \mathrm{~b}$ \\
Black & $23.2 \mathrm{ab}$ & $37.8 \mathrm{ab}$ & $57.5 \mathrm{a}$ & $39.50 \mathrm{bc}$ \\
Blue & $16.7 \mathrm{~b}$ & $28.8 \mathrm{ab}$ & $49.0 \mathrm{a}$ & $31.50 \mathrm{bc}$ \\
White & $8.3 \mathrm{~b}$ & $11.2 \mathrm{~b}$ & $45.8 \mathrm{a}$ & $21.78 \mathrm{c}$ \\
\hline
\end{tabular}

Means based on six traps per color per test. Means, within the same column, followed by the same letter are not significantly different $(P=0.05$; Duncan's multiple range test $)$.

as a standard for comparing the different baits tested. An index value for each bait was calculated by dividing the number of flies caught by that bait by the standard in that experiment (e.g., SFA + $\mathrm{H}_{2} \mathrm{O} 45.8 /$ SGM $55.8=0.82$ ) (Table 6). IGM had the highest index value and SGM the second highest. The addition of water to the SFA formulation resulted in a higher index value than the dry SFA. The TRH+I+LA chemical combination had a higher index value than any of the other chemical combinations and the fishmeal. TRH+I+AS and $\mathrm{TRH}+\mathrm{I}+\mathrm{LA}+\mathrm{AS}$ had lower index values than indole and $\mathrm{TRH}+\mathrm{I}$, which suggests that the addition .of ammonium sulfate could decrease the attractiveness of the SFA formulation. The index value for GM was lower than for any of the chemical combinations and indole but was slightly greater than for trimethylamine hydrochloride, linoleic acid, and ammonium sulfate.

\section{Diseussion}

Using the baited jug-trap for a fly monitoring program, the greatest number of flies would be trapped at the roof peak, but the rafter level location would be more convenient for trap servicing and would yield an adequate sample of flies in a narrow caged-layer poultry house. The lack of effectiveness of the traps located near the manure could have been due to the high attractiveness of the manure itself.

With a different trap results may differ. Mitchell et al. (1975), using bait in pans, found fewer flies attracted at positions further away from the manure (rafter level) than at the manure level. In our experiments, the outside traps were more exposed (unprotected) and attracted fewer flies than those traps at the same level inside the house. Mitchell et al. (1975) obtained similar results with a different trap, i.e., traps placed outside the house caught fewer flies than traps at the same height inside the house.

In the high-rise house, the baited jug trap caught the most flies when located near the manure. The results differ from those found in the narrow cagedlayer house tests, where the manure-level traps 


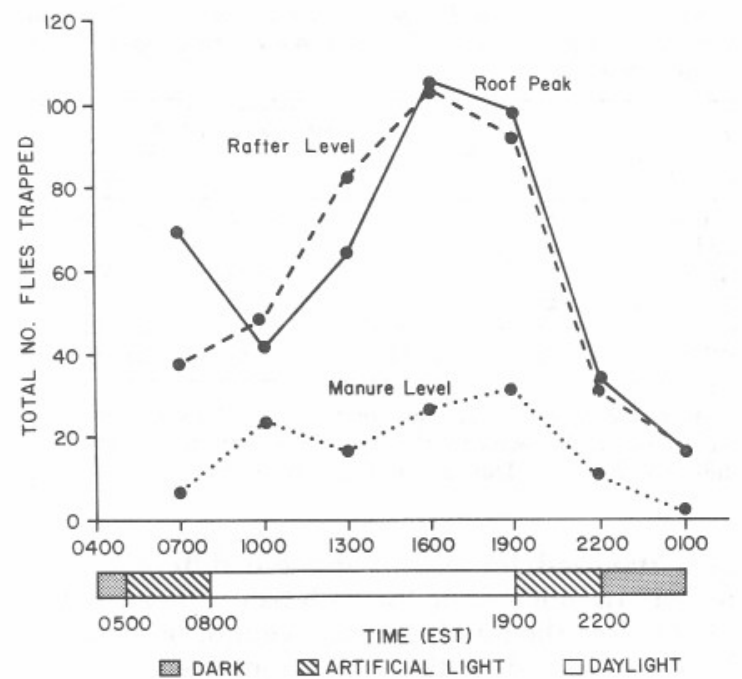

Fig. 4. House flies caught in baited jug-trap at three levels at 3 -h intervals in a caged-layer poultry house.

caught fewer flies than the rafter-level traps. The manure-level trap's high catch in the high-rise house may be attributed to the difference in size of the two structures; the high-rise was larger than the narrow caged-layer (the distance from the manure to the roof peak in the narrow house was approximately equal to the distance from the manure to the walkway in the high-rise). There were some differences in numbers of flies caught at the different horizontal locations. Willson and Mulla (1975) observed a change in spatial response in California as the fly season progressed. The west end of a poultry house attracted the most flies at the beginning of the season (Mar.-Apr.) with a change toward the south, then southeast and northeast (Aug.), and finally back to southeast and southwest (Oct.-Nov.). In our experiments, the west- and south-positioned traps caught consistently more flies than the traps in the other locations at all three vertical levels. These results agree with Willson and Mulla's (1975) observations on the spatial response of flies during the early months of the fly season.

The use of a yellow trap would increase the number of flies caught. All of the colored traps caught more flies than the white trap, which is in agreement with published reports that dark colors or colors with low visual reflectance attract more flies than bright colors when tested on painted surfaces. Freeborn and Berry (1935) counted fly specks on a multicolored plywood board to determine color preferences of the house fly. Waterhouse

Table 5. Mean no. house flies caught per trap baited with different bait formulations and components in a narrow caged-layer poultry house

\begin{tabular}{|c|c|c|c|c|c|}
\hline \multirow{2}{*}{ Bait $^{a}$} & \multicolumn{5}{|c|}{ Mean no. flies per trap per test } \\
\hline & A & $\mathrm{B}$ & $\mathrm{C}$ & $\mathrm{D}$ & Mean \\
\hline & \multicolumn{5}{|c|}{ Experiment 1} \\
\hline IGM & $201.75 a$ & $148.25 \mathrm{a}$ & $189.00 \mathrm{a}$ & $218.75 \mathrm{a}$ & $189.4 a$ \\
\hline SGM & $29.25 b$ & $120.75 b$ & $98.75 b$ & $194.25 \mathrm{a}$ & $110.8 \mathrm{~b}$ \\
\hline SFA & $10.75 b$ & $54.25 b$ & $76.25 b$ & $119.50 \mathrm{~b}$ & $65.2 \mathrm{bc}$ \\
\hline \multirow[t]{2}{*}{ GM } & $4.00 \mathrm{~b}$ & $2.75 c$ & $16.75 \mathrm{~b}$ & $13.50 \mathrm{c}$ & $9.2 \mathrm{c}$ \\
\hline & \multicolumn{5}{|c|}{ Experiment 2} \\
\hline IGM & $94.00 \mathrm{a}$ & $123.75 \mathrm{a}$ & $170.50 \mathrm{a}$ & $146.25 \mathrm{a}$ & $133.6 \mathrm{a}$ \\
\hline SGM & $76.75 \mathrm{ab}$ & $73.25 \mathrm{a}$ & $38.50 \mathrm{~b}$ & $34.75 b$ & $55.8 \mathrm{~b}$ \\
\hline $\mathrm{SFA}+\mathrm{H}_{2} \mathrm{O}$ & $25.00 \mathrm{ab}$ & $58.00 \mathrm{a}$ & $46.75 b$ & $53.25 \mathrm{~b}$ & $45.8 \mathrm{~b}$ \\
\hline \multirow[t]{2}{*}{ GM } & $6.50 \mathrm{~b}$ & $8.50 \mathrm{a}$ & $2.00 \mathrm{~b}$ & $3.50 \mathrm{~b}$ & $5.1 \mathrm{c}$ \\
\hline & \multicolumn{5}{|c|}{ Experiment 3} \\
\hline SGM & $90.75 \mathrm{a}$ & $47.00 \mathrm{a}$ & $61.75 a$ & $18.75 a$ & $54.6 \mathrm{a}$ \\
\hline SFA & $48.00 \mathrm{a}$ & $19.75 b$ & $17.00 \mathrm{~b}$ & $7.00 \mathrm{~b}$ & $22.9 \mathrm{~b}$ \\
\hline Fishmeal & $21.00 \mathrm{a}$ & $10.50 \mathrm{~b}$ & $5.50 \mathrm{~b}$ & $4.75 b$ & $10.4 \mathrm{~b}$ \\
\hline \multirow[t]{2}{*}{$\mathrm{TRH}+\mathrm{I}+\mathrm{LA}+\mathrm{AS}$} & $16.75 \mathrm{a}$ & $6.00 \mathrm{~b}$ & $6.00 \mathrm{~b}$ & $4.25 \mathrm{~b}$ & $8.2 \mathrm{~b}$ \\
\hline & \multicolumn{5}{|c|}{ Experiment 4} \\
\hline SGM & $51.50 \mathrm{a}$ & $45.75 \mathrm{a}$ & $28.75 \mathrm{a}$ & $23.50 \mathrm{a}$ & $37.4 \mathrm{a}$ \\
\hline $\mathrm{TRH}+\mathrm{I}+\mathrm{LA}$ & $7.00 \mathrm{~b}$ & $15.75 b$ & $7.25 \mathrm{a}$ & $4.25 \mathrm{~b}$ & $8.6 b$ \\
\hline $\mathrm{TRH}+\mathrm{I}$ & $7.00 \mathrm{~b}$ & $7.75 b$ & $7.00 \mathrm{a}$ & $2.25 b$ & $6.0 \mathrm{~b}$ \\
\hline \multirow[t]{2}{*}{$\mathrm{TRH}+\mathrm{I}+\mathrm{AS}$} & $5.75 b$ & $7.75 b$ & $5.00 \mathrm{a}$ & $2.75 \mathrm{~b}$ & $5.3 \mathrm{~b}$ \\
\hline & \multicolumn{5}{|c|}{ Experiment 5} \\
\hline SGM & $4.20 \mathrm{a}$ & $16.60 \mathrm{a}$ & $16.80 \mathrm{a}$ & $13.80 \mathrm{a}$ & $12.8 \mathrm{a}$ \\
\hline I & $1.00 \mathrm{~b}$ & $2.00 \mathrm{~b}$ & $3.40 \mathrm{~b}$ & $2.40 \mathrm{~b}$ & $2.2 \mathrm{~b}$ \\
\hline TRH & $0.40 \mathrm{~b}$ & $0.40 \mathrm{~b}$ & $0.80 \mathrm{~b}$ & $1.40 \mathrm{~b}$ & $0.8 \mathrm{~b}$ \\
\hline $\mathrm{LA}$ & $0.20 \mathrm{~b}$ & $0.40 \mathrm{~b}$ & $1.00 \mathrm{~b}$ & $1.60 \mathrm{~b}$ & $0.8 \mathrm{~b}$ \\
\hline AS & $0.40 \mathrm{~b}$ & $0.40 \mathrm{~b}$ & $1.40 \mathrm{~b}$ & $0.80 \mathrm{~b}$ & $0.8 \mathrm{~b}$ \\
\hline
\end{tabular}

Means based on four traps per test in experiments 1 through 4 and five traps per test in experiment 5 . Means followed by the same letter within the same column within each experiment are not significantly different $(P=0.05$; Duncan's multiple range test).

${ }^{a}$ IGM, Improved Golden Malrin; SGM, Super Golden Malrin; SFA, slow-release synthetic fly attractant formulation; GM, Golden Malrin; TRH, trimethylamine hydrochloride; I, indole; LA, linoleic acid; AS, ammonium sulfate. 
Table 6. Index value of each bait formulation or component expressed as a ratio of the no. flies caught with the test bait to the no. flies caught with the standard bait, SGM, in each experiment (Table 5)

\begin{tabular}{lc}
\hline \multicolumn{1}{c}{ Bait $^{a}$} & Index $^{b}$ \\
\hline IGM & 2.05 \\
SGM & 1.00 \\
SFA + $\mathrm{H}_{2} \mathrm{O}$ & 0.82 \\
SFA & 0.50 \\
TRH+I+LA & 0.23 \\
Fishmeal & 0.19 \\
I & 0.17 \\
TRH+I & 0.16 \\
TRH+I+LA+AS & 0.15 \\
TRH+I+AS & 0.14 \\
GM & 0.09 \\
TRH & 0.06 \\
LA & 0.06 \\
AS & 0.06 \\
\hline
\end{tabular}

${ }^{a}$ IGM, Improved Golden Malrin; SGM, Super Golden Malrin; SFA, slow-release synthetic fly attractant formulation; GM, Golden Malrin; TRH, trimethylamine hydrochloride; I, indole; LA, linoleic acid; AS, ammonium sulfate.

${ }^{b}$ Index determined by mean when bait was used in more than one experiment.

(1947) demonstrated that visual reflectance of a color was important in attracting house flies; dusky blue, red, yellow, and green attracted more flies than white and also had a lower reflectance than white. An exception has been reported by Mitchell et al. (1975): sticky panels painted white, silver, navy gray, or solar yellow caught more flies than panels painted blue, black, brown, green, tangerine, or red. Mitchell et al. (1975) also found no color to be more attractive than another; they used pie pan traps baited with trichlorfon and dichlorvos combined with sugar and treated with muscalure. This supports Waterhouse's (1947) conclusion that olfactory responses are stronger than visual cues for house fly orientation. Hecht (1970) concluded that the color itself may not be as important as the contrast of the color with the surrounding environment. Perhaps the yellow trap used in our study would not catch as many flies as another color under different environmental conditions or with different house designs. The unpainted translucent white trap caught enough flies to be useful, and at high fly population levels there was no significant difference in number caught among the different colored traps (including natural white). At low fly population levels, the yellow trap would be more likely to catch flies than would the white trap. The natural, unpainted translucent white jug is the easiest and most practical to use in routine monitoring.

A fly monitoring program using baited traps would be most effective when the traps are used during the periods of greatest fly activity. Parker (1962) showed that the house fly had two activity peaks during the daylight hours, a small morning peak soon after activity started, and then a higher and more prolonged peak in the afternoon. Our results clearly showed an afternoon peak at the roof-peak and rafter-level positions. There was no definite morning peak observed at any of the three positions. The roof-peak and rafter-level positions showed more pronounced changes in activity than the manure level as evidenced by the greater number of flies caught at those positions. Baited jugtraps would be most effective when positioned a few hours before the onset of the observed activity period (1200-1900 h and left in place long enough to cover the decline in activity by the late evening hours. However, in a practical fly monitoring program it may be most convenient to leave the traps in place for several days, in which case the bait should be changed at least once a week.

Although our experiments used SGM as the standard bait in the jug-traps, IGM is superior: 2 -fold more flies are caught. In all of the tests, the traps baited with the Mulla et al. (1977) formulation, SFA, caught fewer flies than the traps baited with IGM or SGM, but caught more flies than GMbaited traps in all of the tests. The addition of water to SFA did not significantly increase the attractiveness of the SFA formulation. The attractiveness of SFA was found to be approximately divided between the fishmeal and the three chemicals, TRH $+\mathrm{I}+\mathrm{LA}$, while the fourth chemical, ammonium sulfate, apparently decreased the attractiveness of the formulation. Indole provided most of the attractiveness of the SFA formulation. Traps baited with trimethylamine hydrochloride, linoleic acid, or ammonium sulfate caught fewer flies than GM-baited traps. Mulla et al. (1977) found traps baited with $\mathrm{SFA}+\mathrm{H}_{2} \mathrm{O}$ caught significantly more flies than IGM- or SGM-baited traps, and the addition of ammonium sulfate slightly increased the attractiveness of the formulation. Mulla et al. (1977) also found the fishmeal not to be attractive to the flies. The experimental procedure used in the two studies may account for the differences in results. Mulla et al. (1977) used $2 \mathrm{~g}$ of bait in traps which were placed 5 or $8 \mathrm{~cm}$ above the ground and were held for 3 or 4 days before counts were made. In our experiments, $25 \mathrm{~g}$ of bait were used in all of the tests and an increase in SGM from 6 to $25 \mathrm{~g}$ increased the fly catch by ca. 3-fold (Axtell, unpublished data). SGM-baited traps were found to be more effective in catching flies when positioned above the cages (rafter level). Our data suggest that Mulla et al. (1977) used a position and an amount of bait (SGM) that was not optimum for a baited trap. The difference in exposure time (3-4 days versus $24 \mathrm{~h}$ ) may also have contributed to the differences in the results between the two studies.

Based on our data, we suggest that the baited jug-trap is a practical method for monitoring house fly populations in caged-layer poultry houses. This method has been used routinely in a poultry pest management program in North Carolina. However, the color of the trap and its manner of use must be standardized. To catch the most flies the traps should be painted yellow. For routine mon- 
itoring, unpainted, white, translucent 3.8-liter plastic jugs are satisfactory and offer the advantages of being inexpensive and readily available. The traps must be located in the same places routinely in each house, with several traps (4-6) per house. A practical and satisfactory arrangement is to hang the traps from the rafters slightly above the upper cages, where the traps can be reached for servicing. Precise locations will depend upon the house design. With multiple aisles in the house it would be preferable (and most practical) to hang the traps at the ends and along the outside aisles of the house. Each jug-trap should contain $25 \mathrm{~g}$ of Improved Golden Malrin renewed at least weekly after removing, counting, and identifying the trapped flies. Although this trap was evaluated for house fly monitoring, some other species of flies (especially Ophyra spp.) were caught, but not in large enough numbers for analysis.

\section{Acknowledgment}

This is Paper No. 9096 of the Journal Series of the N.C. Agric. Res. Serv.

\section{References Cited}

Axtell, R. C. 1970a. Integrated fly-control program for caged-poultry houses. J. Econ. Entomol. 63: 400405.

1970b. Fly control in caged-poultry houses: comparisons of larviciding and integrated control programs. Ibid. 63: 1734-1737.

1981a. Use of predators and parasites in filth fly IPM programs in poultry housing, pp. 26-43. In Status of biological control of filth flies. U.S. Dep. Agric. Sci. Educ. Adm. Publ. A 106.2: F64.

1981b. Livestock integrated pest management (IPM): principles and prospects, pp. 31-40. In F. W. Knapp [ed.], Systems approach to animal health and production: a symposium. University of Kentucky, Lexington.

Brown, A. W. A., A. S. West, and A. S. Lockley. 1961. Chemical attractants for the adult house fly. J. Econ. Entomol. 54: 670-674.
Carlson, D. A., and M. Beroza. 1973. Field evaluation of (Z)-9-tricosene, a sex pheromone of the house fly. Environ. Entomol. 2: 555-559.

Freeborn, S. B., and L. J. Berry. 1935. Color preferences of the house fly, Musca domestica L. J. Econ. Entomol. 28: 913-916.

Gahan, J. B., R. S. Anders, H. Highland, and H. G. Wilson. 1953. Baits for the control of resistant flies. Ibid. 46: 965-969.

Hecht, O. 1963. On the visual orientation of houseflies in their search of resting sites. Entomol. Exp. Appl. 6: 107-113.

1970. Light and color reactions of Musca domestica under different conditions. Bull. Entomol. Soc. Am. 16: 94-98.

Keller, J. C., H. G. Wilson, and C. N. Smith. 1956. Bait stations for the control of house flies. J. Econ. Entomol. 49: 751-752.

Mitchell, E. R., F. C. Tingle, and D. A. Carlson. 1975. Effect of muscalure on house fly traps of different color and location in poultry houses. J. Ga. Entomol. Soc. 10: 169-174.

Mulla, M. S., Y.-S. Hwang, and H. Axelrod. 1977. Attractants for synanthropic flies: chemical attractants for domestic flies. J. Econ. Entomol. 70: 644648.

Parker, A. H. 1962. Studies on the diurnal rhythms of the housefly, Musca domestica L., in a dry tropical environment. Acta Tropica 19: 97-119.

Pickens, L. G., R. W. Miller, and G. R. Moury. 1973. An improved bait for flies (Diptera: Muscidae, Calliphoridae). J. Med. Entomol. 10: 84-88.

Pickens, L. G., R. W. Miller, and L. E. Campbell. 1975. Bait-light combinations evaluated as attractants for house flies and stable flies (Diptera: Muscidae). Ibid. 11: 749-751.

Waterhouse, D. F. 1947. The effect of colour on the numbers of houseflies resting on painted surfaces. Aust. J. Sci. Res. 1: 65-75.

Willson, H. R., and M. S. Mulla. 1973. Attractants for synanthropic flies. 2. Response patterns of house flies to attractive baits on poultry ranches. Environ. Entomol. 2: 815-882.

1975. Spatial and temporal trends of house fly responses to an attractive bait on poultry ranches. Ibid. 4: 395-399.

Received for publication 31 January 1984; accepted 23 April 1984. 